\title{
AN EVALUATION OF DIAGNOSTIC ACCURACY OF C-REACTIVE PROTEIN, TOTAL LEUKOCYTE COUNT, NEUTROPHIL COUNT AND ULTRASONOGRAPHY IN DIAGNOSIS OF ACUTE APPENDICITIS
}

\author{
Umeshchandra D. G1, Puneeth Thalasta ${ }^{2}$
}

1 Professor and HOD, Department of General Surgery, M. R. Medical College, Kalaburagi.

2Postgraduate Student, Department of General Surgery, M. R. Medical College, Kalaburagi. \begin{abstract}
BACKGROUND

Acute appendicitis remains the most frequent cause of lower abdominal pain requiring surgery. The diagnosis of acute appendicitis relies largely on clinical assessment, but in the era of evidence based medicine many studies have looked at various simple blood tests and clinical criteria in an attempt to improve diagnostic accuracy. The total leukocyte count (TLC), neutrophil count, ultrasonography (USG) and C-reactive Protein (CRP) are now often used to aid in the clinical assessment in patients with right iliac fossa pain.

To conclude, an exact diagnosis of acute appendicitis is important for proper management. This study aims at comparing the few known and proven investigations for appendicitis like CRP, neutrophil count, total leukocyte count and ultrasonography; comparing how specific and sensitive each one is, which is best and has maximum positive predictive value. This would be done by comparing it with histopathology report.
\end{abstract}

\section{MATERIALS AND METHODS}

The study is observational study. The total sample was 50 . Sample size was taken conveniently. Patients who have been clinically diagnosed of having acute appendicitis and posted for emergency appendectomy in General Surgery Department, Basaveshwar Teaching and General Hospital attached to Mahadevappa Rampure Medical College, Kalaburagi, during the period from December 2015 to June 2017 were included in the study. All the appendectomy specimens were subjected to histological examination postoperatively, which was taken as the gold standard. The four investigation results were correlated with histopathological examination reports to evaluate their role in diagnosis of acute appendicitis.

\section{RESULTS}

In the present study, USG had the highest sensitivity of $95.56 \%$ followed by CRP $66.67 \%$, TLC 57.78\% and neutrophil count $51.11 \%$. In terms of specificity TLC had $100 \%$, CRP and neutrophil count had about $80 \%$ each and USG had $20 \%$. The most common per operative finding was acutely inflamed appendix (66\%) followed by gangrenous appendix (22\%), normal appendix (10\%) and perforated appendix (2\%). However, histopathological diagnosis was acute appendicitis in 90\% and normal histology was seen in $10 \%$ cases.

\section{CONCLUSION}

When all the three tests are combined (either/ all) the sensitivity, specificity, positive predictive value and negative predictive value, chances of negative appendectomies decrease significantly. It was observed that when all the three tests were negative, appendicitis could be safely ruled out and the surgery could be deferred in these patients. We continue to stress that history and clinical examination by a skilled surgeon still remain indispensable in diagnosing acute appendicitis and its importance cannot be undermined.

\section{KEYWORDS}

Appendicitis, C-Reactive Protein, Neutrophil Count, Ultrasonography.

HOW TO CITE THIS ARTICLE: Umeshchandra DG, Thalasta P. An evaluation of diagnostic accuracy of C-reactive protein, total leukocyte count, neutrophil count and ultrasonography in diagnosis of acute appendicitis. J. Evolution Med. Dent. Sci. 2017;6(91): 6470-6475, DOI: $10.14260 /$ jemds/2017/1406

\section{BACKGROUND}

Acute appendicitis is the most common cause of an 'acute abdomen' in young adults. ${ }^{1}$ Notwithstanding advances in modern radiographic imaging and diagnostic laboratory investigations, the diagnosis of appendicitis remains

'Financial or Other Competing Interest': None.

Submission 16-10-2017, Peer Review 08-11-2017,

Acceptance 15-11-2017, Published 27-11-2017.

Corresponding Author:

Dr. Puneeth Thalasta,

Room No. 203,

Chandrakankt Patil Memorial of Boys Hostel,

Basaveshwara Teaching and General Hospital Campus,

Sedam Road.

E-mail: puneeththalasta17@gmail.com

DOI: $10.14260 /$ jemds $/ 2017 / 1406$

essentially clinical requiring a mixture of observation, clinical acumen and surgical science. In an age accustomed to early and accurate preoperative diagnosis, acute appendicitis remains an enigmatic challenge and a reminder of the art of surgical diagnosis. ${ }^{1}$ Acute appendicitis is one of the most common causes of an abdominal emergency. Acute appendicitis with protean manifestations may simulate almost any other acute abdominal conditions and in turn may be mimicked by a variety of conditions. ${ }^{2}$

It is estimated that the accuracy of clinical diagnosis of acute appendicitis is lying between $76 \%$ and $92 \%{ }^{3}$

Appendectomy for suspected acute appendicitis is a common procedure. The rate of normal appendices unnecessarily being removed remains high (15\% - 30\%), 4 despite several techniques. On one hand a normal appendix at appendectomy represents a misdiagnosis; on the other hand, 
a delayed diagnosis of appendicitis may lead to perforation and peritonitis.

Equally distressing is the fact that perforation may occur in up to $35 \%$ of cases, ${ }^{5}$ so traditionally surgeons have accepted a higher incidence of unnecessary appendectomies in order to decrease the incidence of perforation. This approach is being increasingly questioned in today's era of evidence based medicine. The high rate of negative explorations for appendicitis is a burden faced not only by the general surgeon, but also by the patient and the society as a whole; since appendectomy like any other operation results in socioeconomic impacts in the form of hospital expenses, lost working days and declined productivity. ${ }^{6}$

The goal of surgical treatment is removal of an inflamed appendix before perforation with a minimal number of negative appendectomies.

\section{Objectives of the Study}

1. To find out the specificity, sensitivity, predictive value of positive test and predictive value of negative test of CRP, total leukocyte count, neutrophil count and USG in diagnosing acute appendicitis.

2. To correlate HPE report with the blood investigation reports (CRP, total leukocyte count, neutrophil count) and USG in clinically diagnosed cases of acute appendicitis.

3. To interpret the efficacy to improve the diagnosis and decision making of acute appendicitis and hence reduce negative appendectomies with the help of these investigations.

\section{MATERIALS AND METHODS}

The study is observational study. The total sample was 50 . Sample size was taken conveniently. Patients who have been clinically diagnosed of having acute appendicitis and posted for emergency appendectomy in General Surgery Department, at Basaveshwar Teaching and General Hospital attached to MR Medical College, Kalaburagi, during the period from December 2015 to June 2017 were included in the study.

\section{Inclusion Criteria}

All patients who were diagnosed clinically to have acute appendicitis and subjected for appendectomy at Basaveshwar Teaching and General Hospital attached to MR Medical College, Kalaburagi.

\section{Exclusion Criteria}

1. Patients who are managed conservatively are also excluded from the study.

2. Patients admitted for interval appendectomy following recurrent appendicitis or appendicular mass previously treated conservatively are also excluded.

3. Concomitant conditions where CRP/ leukocyte count/ neutrophil count is elevated in acute appendicitis patients with associated diseases like:

a. Rheumatoid arthritis.

b. Systemic lupus erythematosus.

c. Glomerulonephritis.

d. Gout.

e. Inflammatory bowel disease.

f. Any other conditions where CRP was raised.
Patients who are clinically diagnosed of having acute appendicitis were subjected to routine investigations and the tests mentioned in the study. TLC count of more than 11,000 cells $/ \mathrm{mm}^{3}$ was considered positive and neutrophil count of more than $75 \%$ was considered positive.

Ultrasonography results were considered positive if a noncompressible, blind-ending, non-peristaltic bowel loop originating from the caecum (appendix) with maximal compression, the diameter of the appendix was measured in the antero-posterior dimension, if $\geq 6 \mathrm{~mm}$ (Bull's eye or target lesion) was suggestive of acute appendicitis. CRP more than 1 $\mathrm{mg} / \mathrm{dL}$ was considered to be positive.

After obtaining consent, patient was operated and the appendectomy specimen as sent for histopathological examination. The histopathology report was considered as the final diagnosis. The patients were meticulously monitored in the post-operative period for any complications. All patients were followed up in the outpatient department for a period of two months. All the patients recovered uneventfully.

\section{Statistical Method}

Descriptive and inferential statistical analysis has been carried out in the present study. The results were analysed by using SPSS version 18 (IBM Corporation, SPSS Inc., Chicago, IL, USA). Microsoft Word and Excel was used to generate graphs, tables etc. Results on categorical measurements were presented in Number (\%). Fisher Exact test is used to find the significance of study parameters between the groups. Sensitivity, specificity, PPV and NPV was calculated for diagnostic accuracy. A p-value of $<0.05$ was considered to be significant.

\section{RESULTS}

In the study, the age of the patient ranged from 7 years to maximum of 50 years with a mean age of 21.76 years. The maximum number of patients presented in the age group of 11 - $20(52 \%)$ followed by age group 21 - 30 years (26\%) cases. The least number of patients were seen in age group of $41-50$ years $(2 \%)$.

\begin{tabular}{|c|c|c|c|c|c|}
\hline & N & Minimum & Maximum & Mean & $\begin{array}{c}\text { Std. } \\
\text { Deviation }\end{array}$ \\
\hline $\begin{array}{c}\text { Age in } \\
\text { Years }\end{array}$ & 50 & 7 & 50 & 21.76 & 9.059 \\
\hline \multicolumn{5}{|c|}{ Table 1. Mean Age of Study Participants } \\
\hline
\end{tabular}

\section{Gender Distribution in Acute Appendicitis}

In the present study, out of 50 cases only $12(24 \%)$ cases occurred in females and the remaining 38 (76\%) cases occurred in males.

\begin{tabular}{|c|c|c|}
\hline Sex & Frequency & Percent \\
\hline Female & 12 & 24 \\
\hline Male & 38 & 76 \\
\hline Total & $\mathbf{5 0}$ & $\mathbf{1 0 0}$ \\
\hline \multicolumn{2}{|c|}{ Table 2. Distribution of Study Participants based on Sex } \\
\hline
\end{tabular}

In males, the most common age group of presentation of acute appendicitis was between $11-20$ years (44.73\%) followed by the age group of 21 - 30 years (26.31\%). In females, the most common age group of presentation of acute appendicitis was between 11 - 20 years (75\%) followed by 21 - 30 years $(25 \%)$. 


\begin{tabular}{|c|c|c|c|}
\hline \multirow{2}{*}{ Age in Years } & \multicolumn{2}{|c|}{ Frequency } & \multirow{2}{*}{ Total } \\
\cline { 2 - 4 } & Male & Female & \\
\hline $1-10$ & $02(5.26 \%)$ & 0 & $2(4.0 \%)$ \\
\hline $11-20$ & $17(44.73 \%)$ & $9(75 \%)$ & $26(52.0 \%)$ \\
\hline $21-30$ & $10(26.31 \%)$ & $3(25 \%)$ & $13(26.0 \%)$ \\
\hline $31-40$ & $08(21.05 \%)$ & 0 & $8(16.0 \%)$ \\
\hline $41-50$ & $01(2.63 \%)$ & 0 & $1(2.0 \%)$ \\
\hline Total & $\mathbf{3 8 ( 1 0 0 \% )}$ & $\mathbf{1 2}(\mathbf{1 0 0 \% )}$ & $\mathbf{5 0}(\mathbf{1 0 0 \% )}$ \\
\hline \multicolumn{2}{|l|}{ Table 3. Age Distribution of Patients based on Sex } \\
\hline
\end{tabular}

\section{Distribution of Symptoms, Signs and other Parameters}

Among clinical symptoms abdominal pain was present in all patients (100\%), anorexia in $36(72 \%)$ patients, migration of pain in $46(92 \%)$, vomiting in $38(76 \%)$ and fever in $31(62 \%)$ patients.

Among clinical signs right iliac fossa tenderness was seen in 49 patients (98\%), rebound tenderness was seen in 32 (70\%) cases, guarding was seen in 25 (50\%) cases, which reflects severity of inflammation. Other peritoneal signs like Rovsing's sign was elicited in $26(52 \%)$ cases. Tachycardia was observed in 28 (56\%) of cases.

Total leukocyte counts raised in $6(12 \%)$ females, 20 (40\%) male patients with right iliac fossa pain, neutrophil counts raised in $5(10 \%)$ females and 19 (38\%) male patients with right iliac fossa pain. Similarly, CRP levels raised in 10 (20\%) females and 21 (42\%) male patients with right iliac fossa pain.

\begin{tabular}{|c|c|c|c|}
\hline & $\begin{array}{c}\text { Female n (\%) n= } \\
\mathbf{1 2}\end{array}$ & $\begin{array}{c}\text { Male n (\%) n= } \\
\mathbf{3 8}\end{array}$ & Total \\
\hline $\begin{array}{c}\text { Abdominal } \\
\text { pain }\end{array}$ & $12(24)$ & $38(76)$ & $50(100)$ \\
\hline Migrating & $10(20)$ & $36(72)$ & $46(92)$ \\
\hline Anorexia & $7(14)$ & $29(58)$ & $36(72)$ \\
\hline Vomiting & $9(18)$ & $29(58)$ & $38(76)$ \\
\hline Fever & $08(16)$ & $23(46)$ & $31(62)$ \\
\hline \multicolumn{4}{|c|}{ Table 4. Clinical Symptoms according to Gender } \\
\hline
\end{tabular}

\begin{tabular}{|c|c|c|c|}
\hline & Female n (\%) & Male n (\%) & Total n (\%) \\
\hline RIF Tenderness & $12(24)$ & $37(74)$ & $49(98)$ \\
\hline $\begin{array}{l}\text { Rebound } \\
\text { Tenderness }\end{array}$ & 07 (14) & $25(50)$ & $32(64)$ \\
\hline Guarding & $06(12)$ & $19(38)$ & $25(50)$ \\
\hline Tachycardia & $05(10)$ & $23(46)$ & $28(56)$ \\
\hline Rovsing Sign & $03(06)$ & $23(46)$ & $26(52)$ \\
\hline TLC & $06(12)$ & $20(40)$ & $26(52)$ \\
\hline Neutrophil & $05(10)$ & $19(38)$ & $24(48)$ \\
\hline CRP & $10(20)$ & $21(42)$ & $31(62)$ \\
\hline \multicolumn{4}{|c|}{$\begin{array}{l}\text { Table 5. Clinical Signs and Blood Investigations according } \\
\text { to Gender }\end{array}$} \\
\hline
\end{tabular}

\section{Intraoperative Findings of Appendix}

Intraoperative findings according to gender showed that in 50 patients, 11 (22\%) had gangrenous appendix, 33 (66\%) had inflamed and thickened appendix, $5(10 \%)$ had normal appendix and $1(2 \%)$ had perforated appendix.

\begin{tabular}{|c|c|c|}
\hline & Frequency & Percent \\
\hline Normal appendix (NA) & 05 & 10.0 \\
\hline $\begin{array}{l}\text { Inflamed and thickened } \\
\text { (IA) }\end{array}$ & 33 & 66.0 \\
\hline Perforated appendix & 01 & 2.0 \\
\hline Gangrenous appendix & 11 & 22.0 \\
\hline Total & $\mathbf{5 0}$ & 100.0 \\
\hline \multicolumn{3}{|c|}{ Table 6. Intraoperative Findings of Appendix } \\
\hline
\end{tabular}

\section{Histopathological Examination Report}

Histopathological examination findings according to gender showed that in 50 patients, $45(22 \%)$ patients had acute appendicitis, out of which 37 (70\%) were male and 10 (20\%) were female; $5(10 \%)$ had normal appendix, among which 2 $(4 \%)$ were female and $3(6 \%)$ were male patients.

\begin{tabular}{|c|c|c|c|}
\hline & \multicolumn{2}{|c|}{ Frequency } & \multirow{2}{*}{ Percent } \\
\cline { 2 - 4 } & Female n (\%) & Male n (\%) & \\
\hline $\begin{array}{c}\text { Acute appendicitis } \\
\text { (AA) }\end{array}$ & $10(20 \%)$ & $35(70 \%)$ & 90.0 \\
\hline $\begin{array}{c}\text { Normal appendix } \\
\text { (NA) }\end{array}$ & $02(4 \%)$ & $03(6 \%)$ & 10.0 \\
\hline Total & $\mathbf{1 2}(\mathbf{2 4 \% )}$ & $\mathbf{3 8}(\mathbf{7 6 \% )}$ & $\mathbf{1 0 0}$ \\
\hline \multicolumn{2}{|c|}{ Table 7. Histopathological Examination Report } \\
\hline
\end{tabular}

\begin{tabular}{|c|c|c|c|}
\hline \multirow[b]{2}{*}{ USG } & \multicolumn{2}{|c|}{$\begin{array}{l}\text { Histopathological } \\
\text { Examination Report }\end{array}$} & \multirow[b]{2}{*}{$\begin{array}{l}\text { Total } \\
\text { n (\%) }\end{array}$} \\
\hline & $\begin{array}{c}\text { Acute } \\
\text { Appendicitis } \\
\text { n (\%) }\end{array}$ & $\begin{array}{c}\text { Normal } \\
\text { Appendix } \\
\text { n (\%) }\end{array}$ & \\
\hline $\begin{array}{c}\text { Acute } \\
\text { appendicitis }\end{array}$ & $43(86)$ & $04(08)$ & $47(94)$ \\
\hline $\begin{array}{l}\text { Normal } \\
\text { appendix }\end{array}$ & $02(04)$ & $01(02)$ & $3(06)$ \\
\hline Total & $45(90)$ & $05(10)$ & $50(100)$ \\
\hline \multicolumn{4}{|c|}{$\begin{array}{c}\text { Table 8. Correlation of Ultrasound Abdomen and Pelvis } \\
\text { and Histopathological Examination Report }\end{array}$} \\
\hline
\end{tabular}

Fisher exact test, $\mathrm{P}=0.276$, Sensitivity $=95.56 \%$, Specificity $=20.00 \%, \mathrm{PPV}=91.49 \%, \mathrm{NPV}=33.33 \%$, Accuracy $=$ 88.00\%.

\begin{tabular}{|c|c|c|c|}
\hline \multirow{2}{*}{} & \multicolumn{2}{|c|}{$\begin{array}{c}\text { Histopathological } \\
\text { Examination Report }\end{array}$} & \multirow{2}{*}{ Total } \\
& $\begin{array}{c}\text { Acute } \\
\text { Appendicitis } \\
\text { n (\%) }\end{array}$ & $\begin{array}{c}\text { Normal } \\
\mathbf{n}(\%)\end{array}$ & \\
\hline Positive & $26(52)$ & $0(0)$ & $26(52)$ \\
\hline Negative & $19(38)$ & $05(10)$ & $24(48)$ \\
\hline Total & $45(90)$ & $05(10)$ & $50(100)$ \\
\hline \multicolumn{2}{|c|}{ Table 9. Correlation of Total Leukocyte Count and } \\
\multicolumn{2}{|r|}{ Histopathological Examination Report } \\
\hline
\end{tabular}

Fisher exact test, $\mathrm{P}=0.20$, Sensitivity $=57.78 \%$, Specificity $=$ $100 \%, \mathrm{PPV}=100 \%, \mathrm{NPV}=20.83 \%$, Accuracy $=62.00 \%$. 


\begin{tabular}{|c|c|c|c|}
\hline \multirow[b]{2}{*}{$\begin{array}{l}\text { Neutrophil } \\
\text { Count }\end{array}$} & \multicolumn{2}{|c|}{$\begin{array}{c}\text { Histopathological } \\
\text { Examination Report }\end{array}$} & \multirow[b]{2}{*}{$\begin{array}{l}\text { Total } \\
\text { n (\%) }\end{array}$} \\
\hline & $\begin{array}{c}\text { Acute } \\
\text { Appendicitis } \\
\text { n (\%) }\end{array}$ & $\begin{array}{c}\text { Normal } \\
\text { n (\%) }\end{array}$ & \\
\hline Positive & $23(46)$ & $01(02)$ & $24(48)$ \\
\hline Negative & $22(44)$ & $04(08)$ & $26(52)$ \\
\hline Total & $45(90)$ & $05(10)$ & $50(100)$ \\
\hline \multicolumn{4}{|c|}{$\begin{array}{l}\text { Table 10. Correlation of Neutrophil Count and } \\
\text { Histopathological Examination Report }\end{array}$} \\
\hline
\end{tabular}

Fisher exact test, $\mathrm{P}=0.20$, Sensitivity $=51.11 \%$, Specificity= $80.00 \%, \mathrm{PPV}=95.83 \%, \mathrm{NPV}=15.38 \%$, Accuracy $=54.00 \%$

\begin{tabular}{|c|c|c|c|}
\hline \multirow{2}{*}{ CRP } & \multicolumn{2}{|c|}{$\begin{array}{c}\text { Histopathological } \\
\text { Examination Report }\end{array}$} & \multirow{2}{*}{$\begin{array}{c}\text { Total } \\
\text { n (\%) }\end{array}$} \\
\cline { 2 - 3 } & $\begin{array}{c}\text { Acute } \\
\text { Appendicitis } \\
\text { n (\%) }\end{array}$ & $\begin{array}{c}\text { Normal } \\
\mathbf{n}(\%)\end{array}$ & \\
\hline Positive & $30(60)$ & $01(02)$ & $31(62)$ \\
\hline Negative & $15(30)$ & $04(08)$ & $19(38)$ \\
\hline Total & $45(90)$ & $05(10)$ & $50(100)$ \\
\hline Table 11. Correlation of CRP and Histopathological \\
\multicolumn{3}{|c|}{ Examination Report } \\
\hline
\end{tabular}

Fisher exact test, $\mathrm{P}=0.062$, Sensitivity $=66.67 \%$, Specificity $=80.00 \%, \mathrm{PPV}=96.77 \%, \mathrm{NPV}=21.05 \%$, Accuracy $=$ $68.00 \%$

\section{DISCUSSION}

In the study, out of 50 patients $38(76 \%)$ were male and 12 (24\%) were female patients. So, male predominance was seen in the study undertaken. Appendicitis was common in the age group 11 - 20 years, both in male and female patients in the study. Clinical diagnosis was found to be correct in 45 (90\%) of cases and hence the rate of negative appendectomies for acute appendicitis in our study was $5(10 \%)$. Out of 50 patients who underwent operative procedure, abdominal pain was present in all patients (100\%), anorexia in $36(72 \%)$ patients, migration of pain in $46(92 \%)$, vomiting in $38(76 \%)$ and fever in $31(62 \%)$ patients.

Among clinical signs, right iliac fossa tenderness was seen in 49 patients (98\%), rebound tenderness was seen in 32 (64\%) cases, guarding was seen in 25 (50\%) of cases, which reflects severity of inflammation. Other peritoneal signs like Rovsing's sign was elicited in $26(52 \%)$ cases. Tachycardia was observed in 28 (56\%) of cases. The mean age of presentation was 21.76 years. Increased leukocyte count was seen in 26 (52\%) cases, neutrophil count in 24 (48\%) cases and CRP in $31(62 \%)$ cases. The most common intraoperative finding was acutely inflamed appendix 33 (66\%), gangrenous appendix was seen in 11 (22\%), normal appendix in $5(10 \%)$ and followed by perforated appendix $1(2 \%)$ of operated cases.

In our study, clinical diagnosis was found to be correct in $45(90 \%)$ of cases and hence the rate of negative appendectomies for acute appendicitis in our study was 5 (10\%).
Our Study is Compared with other Studies as follows-

\begin{tabular}{|c|c|c|c|c|}
\hline & $\begin{array}{l}\text { Study } \\
\text { Group }\end{array}$ & $\begin{array}{c}\text { HPE } \\
\text { Positive }\end{array}$ & $\begin{array}{c}\text { HPE } \\
\text { Negative }\end{array}$ & $\begin{array}{c}\text { Negative } \\
\text { Appendice } \\
\text { ctomy }\end{array}$ \\
\hline $\begin{array}{l}\text { Subedi } \mathrm{N} \\
\text { et } \mathrm{al}^{7}\end{array}$ & 415 & 317 & 5 & $12(3.5 \%)$ \\
\hline $\begin{array}{l}\text { Subhajit } \\
\text { et al } 8\end{array}$ & 155 & 80 & 9 & $3(13 \%)$ \\
\hline $\begin{array}{l}\text { Ikramullah } \\
\text { Khan et al }^{9}\end{array}$ & 100 & 54 & - & $1(5.6 \%)$ \\
\hline $\begin{array}{l}\text { Nasir Ali } \\
\text { et al10 }\end{array}$ & 50 & 39 & 11 & - \\
\hline $\begin{array}{l}\text { Shefkixharra } \\
\text { et al } 11\end{array}$ & 173 & 148 & 25 & - \\
\hline $\begin{array}{l}\text { Haider Kamran } \\
\text { et al12 }\end{array}$ & 100 & 58 & 19 & $19 \%$ \\
\hline Present Study & 50 & 45 & 5 & $5(10 \%)$ \\
\hline \multicolumn{5}{|c|}{$\begin{array}{l}\text { Table 12. Comparison of Accuracy of Clinical Diagnosis in } \\
\text { Acute Appendicitis with Other Studies }\end{array}$} \\
\hline
\end{tabular}

Subedi $\mathrm{N}$ et $\mathrm{al}^{7}$ concluded that the diagnosis of acute appendicitis is primarily established by the surgeon's evaluation based on clinical features and physical examination. But the cause of acute appendicitis varies. Hence, all appendectomy specimens should be sent for routine histopathological examination in order to determine the surgeon's rate of negative appendectomy with clinical correlation and to determine the aetiological factors.

Histopathological examination showed $1.4 \%$ cases of normal appendix. The accuracy of the clinical diagnosis has been estimated between $76 \%$ and $92 \%$, because of which accurate diagnosis of acute appendicitis is still difficult. However, delay in diagnosis leads to increased rates of morbidity and mortality. On the other hand, the negative rate of appendectomy varies from $15 \%-30 \%$. The problem in making a clinical diagnosis of appendicitis is because of other possible surgical and nonsurgical causes of lower abdominal pain.

Total Leukocyte Count and Acute Appendicitis

\begin{tabular}{|c|c|c|c|c|}
\hline & Sensitivity & Specificity & \begin{tabular}{|c} 
Predictive \\
value \\
Positive \\
Test \\
\end{tabular} & $\begin{array}{c}\text { Predictive } \\
\text { value in } \\
\text { Negative } \\
\text { Test }\end{array}$ \\
\hline $\begin{array}{c}\text { Shefkixharr } \\
\text { a et al } 11\end{array}$ & $79.1 \%$ & $68 \%$ & $93.6 \%$ & - \\
\hline $\begin{array}{c}\text { Haider } \\
\text { Kamran et } \\
\text { al12 }^{12}\end{array}$ & $76.5 \%$ & $73.7 \%$ & $92.5 \%$ & - \\
\hline $\begin{array}{c}\text { Agarwal C S } \\
\text { et al } 13\end{array}$ & $78.6 \%$ & $54.8 \%$ & $81.05 \%$ & $51.1 \%$ \\
\hline $\begin{array}{c}\text { Nasir Ali } \\
\text { et al } 10\end{array}$ & $74.4 \%$ & $72.7 \%$ & $90.6 \%$ & $44.4 \%$ \\
\hline $\begin{array}{c}\text { Pablo } \\
\text { Ortega } \\
\text { Debellon } \\
\text { et al }{ }^{14}\end{array}$ & $86.4 \%$ & $42.9 \%$ & $73.6 \%$ & $62.5 \%$ \\
\hline $\begin{array}{c}\text { Shehzab } \\
\text { Ahmed } \\
\text { Abbasi }^{15}\end{array}$ & $87.5 \%$ & $78.6 \%$ & $91.35 \%$ & $71 \%$ \\
\hline $\begin{array}{l}\text { Present } \\
\text { Study }\end{array}$ & $57.78 \%$ & $100 \%$ & $100 \%$ & $20.83 \%$ \\
\hline
\end{tabular}


On comparing the results of our study with the abovementioned studies, it is inferred that the accurate diagnosis of acute right iliac fossa pain remains a difficult clinical problem, as the differential diagnosis of such pain is not straight forward. In spite of development of various diagnostic scores and diagnostic aids like C-reactive protein, the diagnosis has been confusing for the clinician as no laboratory or radiological test is $100 \%$ accurate. Total leukocyte count (TLC) is one of the helpful investigations in diagnosis of acute appendicitis. The evaluation of role of leukocytosis in the diagnosis of acute appendicitis has a consideration. The diagnostic accuracy of TLC is increased further if combined with CRP, neutrophil count, shift to the left, sequential leukocyte counts and neutrophil: lymphocyte ratio.

\section{USG Abdomen and Acute Appendicitis}

The sensitivity, specificity, positive predictive value of test and negative predictive value of test in our study is $95.56 \%, 20 \%$, $91.49 \%, 33.33 \%$ and accuracy of $88 \%$. Comparison of USG as an investigation of acute appendicitis is compared to the data reported in literature in the following table.

\begin{tabular}{|c|c|c|c|c|c|}
\hline & & & & \\
\hline $\begin{array}{c}\text { Tauro L F } \\
\text { et al }{ }^{16}\end{array}$ & $91.37 \%$ & $88.07 \%$ & $91.37 \%$ & $88.09 \%$ & $90 \%$ \\
\hline $\begin{array}{c}\text { Lohani B } \\
\text { et al } 17\end{array}$ & $78.72 \%$ & $60 \%$ & $94.87 \%$ & $23.07 \%$ & $76 \%$ \\
\hline $\begin{array}{c}\text { Mohammed B } \\
\text { Hassan } \\
\text { et al } 18\end{array}$ & $57.14 \%$ & $94.87 \%$ & $95.65 \%$ & $54.17 \%$ & - \\
\hline $\begin{array}{c}\text { ParigaJavidi } \\
\text { Parsijani et al }\end{array}$ & $71 \%$ & $72.7 \%$ & $88.4 \%$ & $47 \%$ & $72 \%$ \\
\hline $\begin{array}{c}\text { HS Fung } \\
\text { et al } 19\end{array}$ & $75.5 \%$ & $89.7 \%$ & $73.2 \%$ & $91 \%$ & - \\
\hline $\begin{array}{c}\text { Shirzad Nasir } \\
\text { et al }{ }^{20}\end{array}$ & $71.2 \%$ & $83.3 \%$ & $97.4 \%$ & $25 \%$ & $72.4 \%$ \\
\hline Present Study & $95.56 \%$ & $20 \%$ & $91.49 \%$ & $33.33 \%$ & $88 \%$ \\
\hline $\begin{array}{c}\text { Table 14. Comparison of Role of USG Abdomen in diagnosis } \\
\text { of Acute Appendicitis with other Studies }\end{array}$ \\
\hline
\end{tabular}

Tauro LF et al, 16 in the above observation shows that all the cases presented with pain in the right iliac fossa (RIF) and clinical suspicion of acute appendicitis, which were the selection criteria for the present study. Tenderness in RIF was the most common sign elicited in all the cases (100\%). Irrespective of the pathology, vomiting was found to be present in $91 \%$ of the cases. Murphy's triad of symptoms, i.e. pain in the abdomen, vomiting and fever held good in the diagnosis of acute appendicitis in their study.

A total of 58 cases were diagnosed to have appendicular pathology by USG and all these patients were operated upon. Out of the 58 operated cases, 53 were HPE positive and 5 were found to be negative on HPE. The overall specificity (88.09\%) and sensitivity $(91.37 \%)$ of USG in diagnosing appendicular pathology were high, indicating accurate diagnosis by USG in almost all patients with pain in RIF.

\section{C-Reactive Protein and Acute Appendicitis}

C-reactive protein (CRP) was first found in the serum of patients suffering from pneumonia caused by Streptococcus pneumoniae. Together with other acute phase proteins, the serum level of CRP rises in response to any tissue injury. It also increases in response to infections (bacterial and viral) and in non-infectious conditions like myocardial infarction, malignancies and rheumatic disorders. CRP concentration increases within 8 hours of the onset of tissue injury, peaks in 24 - 48 hours and remains high as long as there is continuing infection or tissue destruction. Due to its short half-life (4-7 hours), serum CRP concentration rapidly declines as the acute inflammatory process subsided. Many reports have investigated the value of CRP in improving the diagnostic accuracy of acute appendicitis with conflicting result.

In our study serum CRP estimation in diagnosis of acute appendicitis yielded a sensitivity of $66.67 \%$, specificity of $80 \%$, positive predictive value of $96.77 \%$, negative predictive value of $21.05 \%$ and accuracy of $68 \%$. The sensitivity in our study are compared with other studies as shown in the table below. It is shown that the sensitivity values are comparable with that of the other studies done in the past.

\begin{tabular}{|c|c|c|c|c|}
\hline & & & & \\
& & sे & & \\
\hline $\begin{array}{c}\text { Shefkixharra } \\
\text { et al }\end{array}$ & $81.1 \%$ & $72 \%$ & $94.7 \%$ & \\
\hline $\begin{array}{c}\text { Agarwal CS } \\
\text { et al }\end{array}$ & $74.8 \%$ & $66.7 \%$ & $84.9 \%$ & $51.9 \%$ \\
\hline $\begin{array}{c}\text { Nasir Ali } \\
\text { et al }\end{array}$ & $84.6 \%$ & $90.9 \%$ & $97.1 \%$ & $62.5 \%$ \\
\hline $\begin{array}{c}\text { Pablo Ortega } \\
\text { Debellon } \\
\text { et al }\end{array}$ & $90.9 \%$ & $74.3 \%$ & $79.8 \%$ & $74.3 \%$ \\
\hline Asfar S et al & $93.6 \%$ & $86.6 \%$ & $96.7 \%$ & $76 . \%$ \\
\hline Present Study & $66.67 \%$ & $80 \%$ & $96.67 \%$ & $21.05 \%$ \\
\hline
\end{tabular}

Table 15. Comparison of Role of CRP in diagnosis of Acute Appendicitis with other Studies

\section{Neutrophil Count and Acute Appendicitis}

Out of 50 cases in the study, 24 (48\%) patients had elevated neutrophil count and rest 26 (52\%) patients had normal neutrophil count. Out of those $24(48 \%)$ patients who had elevated neutrophil count, $23(46 \%)$ had acute appendicitis and $1(02 \%)$ normal appendix histopathologically. Out of the $26(52 \%)$ patients where neutrophil count was within normal limits, 22 (44\%) had acute appendicitis and 4 (08\%) had normal appendix as histopathological report. In our study, serum neutrophil count estimation in diagnosis of acute appendicitis yielded a sensitivity of $51.11 \%$, specificity of $80 \%$, positive predictive value of $95.83 \%$ and negative predictive value of $15.38 \%$ and accuracy of $54 \%$.

In a study done by Zuhoor K Al-Gaithy, ${ }^{21}$ four hundred and fifty-six patients (273 males and 183 females) who underwent appendectomy with a clinical diagnosis of Acute Appendicitis in Surgery Department at King Abdulaziz Medical Centre, Jeddah, Saudi Arabia, were recruited in this retrospective 
study between January 2003 and January 2007. The diagnosis of acute appendicitis was established by history, clinical examination and laboratory tests including WBCs and neutrophil counts.

From the study done by Zuhoor $\mathrm{K} \mathrm{Al-Gaithy,} \mathrm{it} \mathrm{was}$ concluded that clinicians should not rely on either elevated TLC or neutrophil count as appendicitis indicator, as clinical data are superior in decision making for appendectomy.

\section{CONCLUSION}

Acute appendicitis was the most common abdominal surgical emergency with male predominance. Appendicitis was commonly observed in the age group of 11 - 20 years followed by 21 to 30 years in this study. The rate of negative laparotomies for acute appendicitis in our study is $10 \%$.

In the present study, USG had the highest sensitivity (95.56\%) followed by CRP (66.67\%), TLC (57.78\%) and neutrophil count (51.11\%). In terms of specificity TLC had $100 \%, \mathrm{CRP}$ and neutrophil count had about $80 \%$ each and USG had $20 \%$. When all the three tests are combined (either/ all) the sensitivity, specificity, positive predictive value and negative predictive value chances of negative appendectomies decrease significantly. It was observed that when all the three tests were negative, appendicitis could be safely ruled out and the surgery could be deferred in these patients.

We continue to stress that history and clinical examination by a skilled surgeon still remain indispensable in diagnosing acute appendicitis and its importance cannot be undermined.

We concluded that if patients with right iliac fossa pain are explored on the basis of USG, preoperative serum CRP levels and TLC and due respect given to the percentage of neutrophil count, negative explorations could be prevented thus preventing the morbidity and burden on hospital resources associated with the negative explorations. Therefore, we recommend performing all three of these laboratory tests in combination along with USG in patients with an equivocal diagnosis of acute appendicitis based on clinical signs alone before surgical exploration.

\section{Limitation of the Study}

Due to short duration of study convenience sampling technique was followed, thus sampling size was taken conveniently. The results of the study cannot be generalised due to the potential bias resulting from the sampling technique and sample size estimation.

\section{REFERENCES}

[1] Peranteau WH, Smink DS. Appendix. Meckel's and other small bowel diverticula. In: Zinner MJ, Stanley AW. eds. Maingot's abdominal operation. $12^{\text {th }}$ edn. New York: The McGraw-Hill Companies 2013:623-40.

[2] Brown SP. Acute appendicitis. In: Ellis BW, Brown SP, eds. Hamilton Bailey's emergency surgery. $13^{\text {th }}$ edn. New York: Arnold 2000:399-400.

[3] Lewis FR, Holcroft JW, Boey J, et al. Appendicitis. A critical review of diagnosis and treatment in 1,000 cases. Arch Surg 1975;110(5):677-84.

[4] Radford-Smith GL, Edward JE, Purdie DM, et al. Protective role of appendicectomy on onset and severity of ulcerative colitis and Chron's disease. Gut 2002;51(6):808-13.
[5] Wakeley CP. The position of the vermiform appendix as ascertained by an analysis of 10,000 cases. J Anat 1933;67(Pt 2):277-83.

[6] Geboes K. Appendiceal function and dysfunction. What are the implications for inflammatory bowel disease? Nat Clin Pract Gastroenterol Hepatol 2005;2:338-9.

[7] Subedi N, Dangol US, Adhikary MB, et al. Acute appendicitis: a 2-year review of clinical presentation and histopathology. Journal of Pathology of Nepal 2011;1(2):104-7.

[8] Peranteau WH, Smink DS. Appendix. Meckel's and other small bowel diverticula. Maingot's abdominal operations. $12^{\text {th }}$ edn. 2013:623-48.

[9] Khan I, ur Rehman A. Application of alvarado scoring system in diagnosis of acute appendicitis. J Ayub Med Coll Abbottabad 2005;17(3):41-4.

[10] Ali N, Rasul S, Mehmood Z, et al. Value of total leukocyte count and C-reactive proteins in the diagnosis of acute appendicitis. Journal of Surgery Pakistan 2009;14(4):153-6.

[11] Xharra S, Gashi-Luci L, Xharra K, et al. Correlation of serum C-reactive protein, white blood count and neutrophil percentage with histopathology findings in acute appendicitis. World J Emerg Surg 2012;7(1):27.

[12] Kamran H, Naveed D, Nazir A, et al. Role of total leukocyte count in diagnosis of acute appendicitis. J Ayub Med Coll Abbottabad 2008;20(3):70-1. http://www.ayubmed.edu.pk/JAMC/70PAST/203/Haider.pdf

[13] Agarwal CS, Adhikari S, Kumar M. Role of serum Creactive protein and leukocyte count in the diagnosis of acute appendicitis in Nepalese population. Nepal Med Coll J 2008;10(1):11-5.

[14] Ortega-Deballon P, de Adana-Belbel RJC, HernandezMatias A, et al. Usefulness of laboratory data in the management of right iliac fossa pain in adults. Dis Colon Rectum 2008;51(7):1093-9.

[15] Abbasi SA, Mishwani AH. Diagnostic accuracy of total leukocyte count and ultrasound in the diagnosis of acute appendicitis. Journal of Rawalpindi Medical College (JRMC) 2012;16(2):147-9.

[16] Tauro LF, Premanand TS, Aithala PS, et al. Ultrasonography is still a useful diagnostic tool in acute appendicitis. Journal of Clinical and Diagnostic Research 2009;(3):1731-6.

[17] Lohani B, Gurung G, Paudel S, et al. Diagnostic efficacy of ultrasonography in acute appendicitis. Journal of Institute of Medicine 2012;34(3):8-11.

[18] Hassan MB, Tawfiq AS, Brayyich AM, et al. The sensitivity and specificity of ultrasound in diagnosis of acute appendicitis. Tikrit Medical Journal 2009;15(2):132-40.

[19] Fung HS, Lau S, Siu JCW, et al. Audit of ultrasonography for diagnosis of acute appendicitis: a retrospective study. J HK Coll Radiol 2008;11:108-11.

[20] Nasiri S, Mohebbi F, Sodagari N, et al. Diagnostic values of ultrasound and the Modified Alvarado Scoring System in acute appendicitis. International Journal of Emergency Medicine 2012;5(1):26.

[21] Al-Gaithy ZK. Clinical value of total white blood cells and neutrophil counts in patients with suspected appendicitis: retrospective study. World Journal of Emergency Surgery 2012;7(1):32. 